\title{
Tick-borne encephalitis presenting as fever without localising signs A case series
}

\author{
Journal Article \\ Author(s): \\ Meyer, Patrick Michael; Zimmermann, Hanspeter; Goetschel, Philippe \\ Publication date: \\ 2010 \\ Permanent link: \\ https://doi.org/10.3929/ethz-b-000018057 \\ Rights / license: \\ In Copyright - Non-Commercial Use Permitted \\ Originally published in: \\ European Journal of Pediatrics 169(6), https://doi.org/10.1007/s00431-009-1097-7
}




\title{
Tick-borne encephalitis presenting as fever without localising signs - a case series
}

\author{
Patrick Michael Meyer • Hanspeter Zimmermann • \\ Philippe Goetschel
}

Received: 9 August 2009 / Accepted: 12 October 2009 / Published online: 4 November 2009

(C) Springer-Verlag 2009

\begin{abstract}
Introduction Tick-borne encephalitis (TBE) presents without neurologic symptoms in 19\% in children less than 16 years in Switzerland (2000-2008). In these cases, fever can be the only leading manifestation.

Case series We report on four hospitalised children who had TBE and presented as fever without localising signs (FWLS) between 2000 and 2008 in an endemic area in Switzerland.

Conclusion TBE infection has to be considered in the differential diagnosis of FWLS in endemic areas. Foremost, FWLS characterised by a biphasic fever course and accompanied by headache in patients in a reduced general condition. Affirming that in patients presenting as FWLS also cases of TBE are contained, this disease is underreported.
\end{abstract}

Financial Support: None.

No authors have any financial/conflicting interests to disclose.

All authors were involved in the retrospective study and in writing the report.

P. M. Meyer $(\bowtie) \cdot$ P. Goetschel

Department of Paediatrics, Triemli Hospital Zurich,

Birmensdorferstrasse 497,

8063 Zurich, Switzerland

e-mail: patrick_meyer@gmx.net

\section{H. Zimmermann}

Division of Communicable Diseases,

Swiss Federal Office of Public Health,

3003 Bern, Switzerland
Keywords Tick-borne encephalitis (TBE) .

Fever without localising signs (FWLS) · Children .

Switzerland

\section{Introduction}

Tick-borne encephalitis (TBE) is caused by TBE virus, a neurotropic flavivirus which causes meningitis, encephalitis and/or myelitis. In approximately one third of patients infected, the second phase of disease develops, characterised by symptoms and signs of meningitis or meningoencephalitis, fever and/or flu-like symptoms $[1,2]$. Meningeal signs usually occur, but may not be pronounced [1]. Children less than 16 years with TBE were reported in up to $19 \%$ without any presence of neurologic symptoms (e.g. neck stiffness, altered state of consciousness, seizures) to the nationwide mandatory notification system in Switzerland during 2000 and 2008.

TBE is endemic in Switzerland with risk areas in the northeast, and therefore, TBE is a mandatory reportable disease in Switzerland. Since the early 1990s, there has been a steady increase of TBE. In 2006, the highest number of cases in recorded history was reported. The epidemiology of TBE is closely related to the persons living in endemic areas for whom an increased risk of exposure is present and to the ecology and biology of ticks. Since 2007, the cases reported annually are about at the same level as before 2006. As a result, Swiss vaccination policy was amended in 2006; the new recommendations advised vaccinating adults and children 6 years of age in endemic areas [2]. 
Table 1 TBE presenting as FWLS, 2000-2008, Department of Paediatrics, Triemli Hospital Zurich

Clinical and laboratory features

\begin{tabular}{|c|c|c|c|c|c|c|c|c|c|c|c|c|c|}
\hline \multirow[t]{2}{*}{ Patient } & \multirow[t]{2}{*}{$\begin{array}{l}\text { Age } \\
\text { (years) }\end{array}$} & \multirow[t]{2}{*}{ Gender } & \multirow[t]{2}{*}{ Season } & \multirow[t]{2}{*}{ Symptoms } & \multicolumn{4}{|l|}{ CSF } & \multicolumn{2}{|c|}{$\begin{array}{l}\text { Inflammatory } \\
\text { parameters }\end{array}$} & \multicolumn{2}{|c|}{$\begin{array}{l}\text { Results of } \\
\text { serologic } \\
\text { testing for } \\
\text { TBE }\end{array}$} & \multirow[t]{2}{*}{$\begin{array}{l}\text { Hospital } \\
\text { stay } \\
\text { (days) }\end{array}$} \\
\hline & & & & & $\begin{array}{l}\text { Total cell } \\
\text { count } \\
(\text { cells } / \mu \mathrm{l})\end{array}$ & $\begin{array}{l}\text { Mononuclear } \\
\text { cells } \\
(\text { cells } / \mu \mathrm{l})\end{array}$ & $\begin{array}{l}\text { Protein } \\
(\mathrm{g} / \mathrm{l})\end{array}$ & $\begin{array}{l}\text { Glucose } \\
(\mathrm{mmol} / \mathrm{l})\end{array}$ & $\begin{array}{l}\text { WBC } \\
\left(10^{9} / 1\right)\end{array}$ & $\begin{array}{l}\text { CRP } \\
(\mathrm{mg} / \mathrm{l})\end{array}$ & $\operatorname{IgM}$ & $\operatorname{Ig} G$ & \\
\hline 1 & 4 & M & November & $\begin{array}{l}\text { Fever }\left(40.0^{\circ} \mathrm{C}\right) \\
\text { headache, vomiting }\end{array}$ & 100 & 27 & 0.30 & 3.0 & 24.8 & 69.7 & + & + & 7 \\
\hline 2 & 7 & M & June & $\begin{array}{l}\text { Fever }\left(39.5^{\circ} \mathrm{C}\right) \\
\text { headache, vomiting }\end{array}$ & 67 & 53 & 0.51 & 2.9 & 11.9 & 3.0 & + & + & 7 \\
\hline 3 & 4 & $\mathrm{~F}$ & July & $\begin{array}{l}\text { Fever }\left(38.5^{\circ} \mathrm{C}\right) \\
\text { headache, vomiting }\end{array}$ & 68 & 57 & 0.30 & 4.1 & 25.9 & 4.9 & + & + & 2 \\
\hline 4 & 9 & M & June & $\begin{array}{l}\text { Fever }\left(39.0^{\circ} \mathrm{C}\right) \\
\text { headache }\end{array}$ & 164 & 51 & 0.58 & 2.9 & 34.5 & 40.5 & + & + & 7 \\
\hline
\end{tabular}

$C S F$ cerebrospinal fluid, $W B C$ white blood cell count, $C R P$ C-reactive protein

\section{Materials and methods}

Between 2000 and 2008, all cases of TBE occurring in children less than 16 years were retrospectively assessed at our department. The catchment area is one part of canton Zurich, which is a high-risk region for TBE in Switzerland. In all these cases, those with fever as the leading manifestation were further analysed.

The case definition included fever without localising signs (FWLS), cerebrospinal fluid (CSF) pleocytosis and positive TBE serology in blood, i.e. IgG and IgM antibodies directed against TBE virus (FSME ELISA, Genzyme Virotech $\mathrm{GmbH}$, Rüsselsheim, Germany; sensitivity for $\operatorname{IgG}$ and $\operatorname{IgM}>99.8 \%$, specificity for $\operatorname{IgG} 95.6 \%$ and $\operatorname{IgM}>99.8 \%$ ).

The quest for TBE infection in children with FWLS living in an endemic area for TBE was prompted because of clinical features in addition to FWLS, which included a biphasic fever course, headache and a reduced general condition.

Table 2 Recorded cases of TBE in Switzerland, 2000-2008, notifications by age and presence of neurologic symptoms

\begin{tabular}{lrcr}
\hline & Total & $\begin{array}{l}\text { Neurologic } \\
\text { symptoms, } n(\%)\end{array}$ & $\begin{array}{l}\text { Without neurologic } \\
\text { symptoms, } n(\%)\end{array}$ \\
\hline All ages & 1,177 & $1,006(85)$ & $171(15)$ \\
$<16$ years & 192 & $156(81)$ & $36(19)$ \\
$<6$ years & 34 & $28(82)$ & $6(18)$ \\
\hline
\end{tabular}

\section{Results}

At our department, 26 patients (median age 6.0 years, range 3-16) were tested for TBE between 2000 and 2008, whereof ten patients presented as FWLS.

Five patients had a positive TBE serology in blood, i.e. serum antibodies directed against TBE virus were present in positive titres.

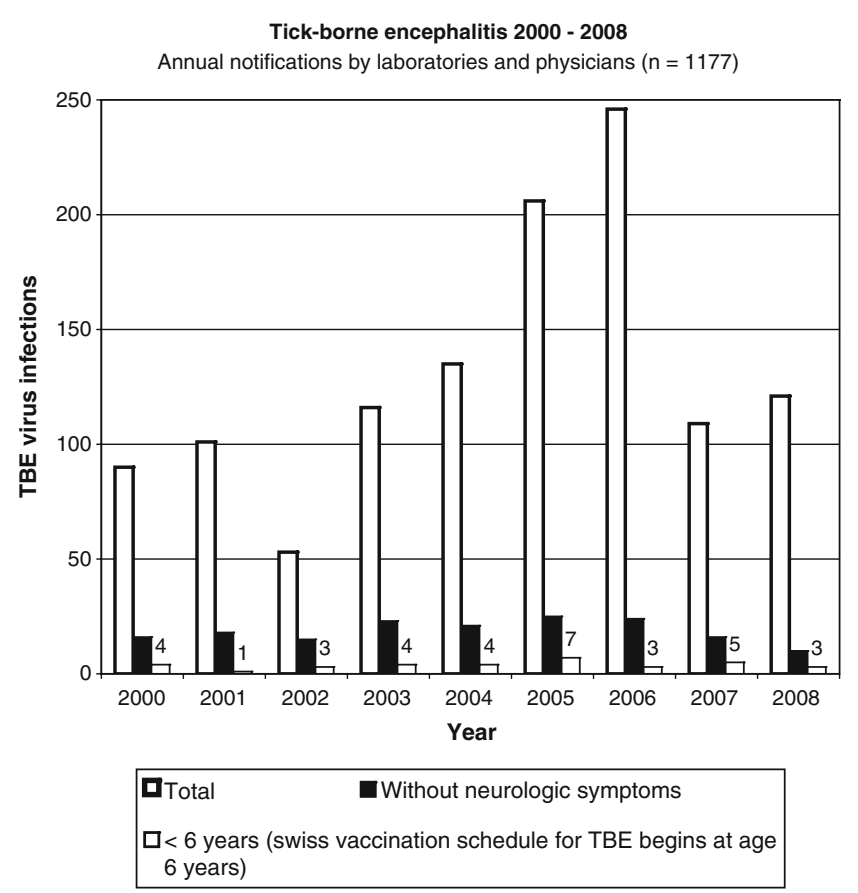

Fig. 1 Recorded cases of TBE in Switzerland, 2000-2008, annual notifications 
The case definition with FWLS and cerebrospinal fluid pleocytosis was fulfilled in four of these five hospitalised children (three males, one female). Only one patient with TBE expressed meningeal signs (neck stiffness) and was excluded from the study.

The median age was 5.8 years (range 4-9; Table 1). All patients presented with fever $\left(38.5-40.0^{\circ} \mathrm{C}\right)$, with a characteristic biphasic course. There were no signs of meningoencephalitis. Clinical severity of the acute hospital course was given on the basis of reduced general condition and headache (all patients), as well as additional vomiting (three patients). No patient was immunised with TBE vaccine. One patient recalled a tick bite. CSF analysis showed pleocytosis of 84 cells/ $\mu$ l (range 67-164) with 52 mononuclear (27-57). CSF protein and glucose were $0.41 \mathrm{~g} / 1(0.30-0.58)$ and $2.9 \mathrm{mmol} / \mathrm{l}(2.9-4.1)$, respectively. The peripheral white blood cell count was $25.3 \times 10^{9} / 1(11.9-34.5)$ with normal distribution; C-reactive protein was $22.7 \mathrm{mg} / 1$ (3-69.7).

The median length of hospital stay was 7 days (2-7). No seizures or neurological after-effects occurred. The patients recovered completely and were discharged without sequelae.

\section{Conclusion}

The aim of this study was to evaluate cases of TBE presenting as FWLS, especially without signs of meningoencephalitis. The four presented patients developed only FWLS during TBE virus infection.

Due to the retrospective data collection, we cannot make a statement about total cases presenting as FWLS to our emergency department in the period above because we do not document the initially working hypothesis FWLS. Therefore, we can only mention how many patients with FWLS were tested for TBE (four positive and six negative), but we cannot declare how many were not tested at all.
Thus, further studies involving more cases with a prospective data collection are needed.

Based on our data, the emphasis in managing children with FWLS in endemic areas should be on diagnosing TBE; foremost, FWLS characterised by a biphasic fever course and accompanied by headache in patients in a reduced general condition. Fever can be the only leading manifestation of TBE. TBE infection therefore has to be considered in the differential diagnosis of FWLS.

Twenty percent of febrile children have FWLS [3]. The incidence for TBE in Switzerland in 2008 was 1.5/10 $/$ year, in endemic areas $6 / 10^{5} /$ year [2]. Affirming that in patients presenting as FWLS also cases of TBE are contained, this disease is underreported. The approach to perform a lumbar puncture (to demonstrate aseptic meningitis) and blood serology (for case inclusion of TBE) evaluating children with FWLS in endemic areas can result in an increase in mandatory TBE notifications 'without neurologic symptoms' (Table 2) and finally in an increase in the incidence for TBE (Fig. 1).

In conclusion, making an early diagnosis of TBE in children with FWLS is essential: first, to separate from several other infections which can cause aseptic meningitis and encephalitis, and second, therefore to minimise and prevent ancillary testing and antibiotic and/or antiviral treatment, respectively.

\section{References}

1. Dumpis U, Crook D, Oksi J (1999) Tick-borne encephalitis. Clin Infect Dis 28:882-890

2. Stähelin-Massik J, Zimmermann H, Gnehm HE (2008) Tick-borne encephalitis in Swiss children 2000-2004: five-year nationwide surveillance of epidemiologic characteristics and clinical course. Pediatr Infect Dis J 27:555-572

3. Waddle E, Jhaveri R (2009) Outcomes of febrile children without localising signs after pneumococcal conjugate vaccine. Arch Dis Child 94:144-147 